\title{
Perception of Unemployment Reasons during Coronavirus Lockdown in Ukraine
}

\author{
Inokentii O. Korniienko* and Beata V. Barchi
}

\author{
Department of Psychology, Faculty of Humanities, Mukachevo State University, 26, Uzhgorodska str., \\ Mukachevo, 89600, Ukraine
}

\begin{abstract}
Work has always been a domain where individuals experience distress. However, in the current pandemic and into the unforeseeable future, job loss and unemployment stress will only exponentially increase. This manuscript represents the vision in vocational psychology which aimed to find out how the perception of the reasons for job cuts of males and females shifted in the first stage of the lockdown, to check and to compare the male's and female's ideas about the causes of their own long-term unemployment and their ideas about possible ways out of the unemployment in the situation of a COVID lockdown in Ukraine.

Methods: The research agenda includes exploring of the unemployment crisis among participants who were divided into three age groups of both gender: younger (18-25-year-old), middle (26-35-year-old), older (36-50-year-old). To characterize unemployment in the pandemic period, the questionnaire consisting of three scales was developed. It aimed to discover the reasons for job cuts, the ideas about the causes of the participants' unemployment, and possible ways out of the unemployment situation. Student t-test was used to determine if the means of two sets of data (male and female of different age groups) are significantly different from each other.

Results: It is revealed that the unemployment in Ukraine among all groups of workers showed the different perception of the reasons for job cuts; their ideas about possible ways out of the unemployment in the situation of a COVID lockdown in Ukraine, which showed the generation gap in the job cuts perception and the basics of the interaction between the employer and the employee.

Conclusions: The study provides deeper insights into the labour market and its personal perception by males and females of different age groups in the first stage of a COVID lockdown. Concerning results, consider the passivity of the unemployed, their inertia and unproductive employment strategies, a decline in trust to the media as employment search, and a growing tendency to despair of the ability to find a job. On the positive side is a growing understanding of education importance.
\end{abstract}

Keywords: Labour market, unemployment, lockdown, job cuts, labour lay-off, COVID-19, pandemic, quarantine.

\section{INTRODUCTION}

The pandemic has overwhelmingly harmed the global economy: consumers stay at home, businesses decrease revenue, and lay off workers and unemployment levels rise sharply. Irrespective of the economic categorisation, many countries are struggling to prevent further economic damage caused by this pandemic.

No matter where in the world or in which sector, the crisis is having a dramatic impact on the world's workforce. Hundreds of millions of jobs have been put on hold by coronavirus shutdowns around the world. In the United States, more than 30 million people, over $15 \%$ of the workforce, have applied for unemployment benefits in recent weeks, which was informed by the US Department of Labor. In Western Europe, joblessness is also increasing.

Moreover, as the COVID-19 crisis potentially inflicts long-lasting emotional trauma and disturbs the

*Address correspondence to this author at the Department of Psychology, Faculty of Humanities, Mukachevo State University, 26, Uzhgorodska str., Mukachevo, 89600, Ukraine; Tel/Fax: +380313121109;

E-mail: innokesha@gmail.com employees' psychological well-being, it will ultimately affect the organization's comfortability level. In addition to imposing severe stress on individuals, from the perspective of the macro level, this pandemic has also ruined the psychology of sustainability. Millions of people around the world are coping with job loss caused by the coronavirus crisis. Whether it is temporary or permanent, unemployment mostly leads to stress, anxiety, depression, and other mental health challenges. Future uncertainty related to the COVID-19 pandemic only adds to the angst. While work can form a core part of a person's identity, worklessness can depress and embitter.

The household survey measures labour force status, including unemployment, by demographic characteristics. The establishment survey calculates nonfarm employment, hours, and earnings by industry. In 2020, the US unemployment rate jumped from 6.2 million in February to 20.5 million in May, as the COVID-19 pandemic caused millions of workers to lose their jobs in a short period [1]. In April 2020, privatesector payrolls reported that unemployment among all groups of workers increased sharply as companies shed their workforces amid various government- 
ordered shutdowns that forced most US economy offline. These statistics were confirmed by the most recent report showing that the unemployment rate jumped to $14.4 \%$ with the loss of 20.5 million jobs, which has not been seen since the Great Depression [1].

More than 120 million workers in India, most of them small traders and daily wage earners, lost jobs in April as economic activity all but ceased after the new coronavirus pandemic forced a nationwide lockdown.

The unemployment rate in February was 7.76 percent and climbed to 8.75 percent in March. For example, Across Asia, millions work in garment and other factories that have thrived largely on exports to Europe. Many were suddenly made jobless by COVID19 shutdowns. The question now will be whether, or how quickly, demand for their products will rebound in a post-pandemic world economy.

In Europe itself, Greece has so far confounded predictions by avoiding the kind of mass outbreaks that have claimed tens of thousands of lives in Italy, France, and Britain. The tourism sector is critical to Greece's economy, employing a fifth of the workforce. The country can only hope not just that airlines and airports reopen, but that the tourists recover a pre-pandemic appetite for air travel [2].

Ukraine has registered 456.800 unemployed citizens as of May 4, an increase of $48 \%$ since the previous year, the State Employment Service reported on May 5. Since the beginning of the coronavirus quarantine, the agency has registered 156.600 people as newly unemployed. To prevent the spread of coronavirus in Ukraine, authorities have imposed extensive restrictions, banning the operation of restaurants, beauty, and leisure establishments all over the country. These measures forced many employees to take unpaid leave and face indefinite disruptions in their income [3].

Yet beyond the economic imponderables, long-term mass joblessness - possibly on the scale of the Great Depression in the 1930s - could pose major social and political challenges. It is suggested that unemployment is going to stay high for some time in Ukraine. What is more, it is reasonable to expect similar levels of stress and despair to be prevalent. Losing a job often equates to the grief of losing a loved one; the emotional trajectory can include any stages of grief, which run from shock and denial, through to anger and bargaining, and eventually to acceptance and hope.
High unemployment often leads to social instability, and the government collapses, which is certainly the worst-case scenario.

The study aimed to find out how the perception of the reasons for job cuts males and females shifted in the first stage of the lockdown, to check and to compare male's and female's ideas from different age groups about the causes of their own long-term unemployment and their ideas about possible ways out of the unemployment in the situation of a COVID lockdown in Ukraine.

\section{MATERIALS AND METHODS}

\section{Participants}

Before the actual survey, the expert approval for the research procedure and materials from Tetiana Scherban, Dr.Sc. in Psychology, Prof., rector of Mukachevo State University was granted. The Science and Technology University Board of Mukachevo State University, as an ethics committee, gave the approval to run the research as they considered it beneficial for the region in the given circumstances of COVID lockdown. Additionally, we received an allowance from the Board to involve students and employees of Mukachevo State University and College for reliability testing of the used questionnaire to focus groups. The preliminary research was also done through Google Forms application.

There were 680 (350 female, 330 male) participants who were all from the Western region of Ukraine. All participants were unemployed for more than one month. Participants' age ranged from 25 to 60 . We divided all participants into three groups: younger, middle, and older age groups of both male and female. The participant's age 18-25 years were included in the younger group. The middle-aged group contained the ones of the age 26-35. 36-60-year-old people were in an older group of participants. The sample was selected using a stratified sampling technique. Participation was voluntary. The goals and the test have been described in the introductory section, so the participants were informed to decide whether to get involved in the research or withdraw from it freely. The participation was voluntary.

\section{Measures}

From April 25 to May 29, an online survey (COVID and job cuts) was conducted using principles of snowballing and by invitation through text messages to 
participating. The survey collected data on job cuts gender variables related to COVID-19 (based on the current knowledge). We created the questionnaire to find out the reasons why people lose their jobs, the ideas about the causes of their own long-term unemployment, and the ideas about possible ways to solve the unemployment situation. We also left open free field and asked our participants to tell us their personal story of loosing of searching for a job. That gave us valuable explanatory data and vivid examples.

The instrument's reliability was calculated through Cronbach's alpha, using the SPSS 22 software (Statistical Package for Social Science). The internal consistency of the scales was found to be good, with Cronbach's alpha values of between 0.79 and 0.88 for the respective three subscales. The Cronbach Alpha reliability coefficient was observed to be 0.76 for younger, 0.88 for middle, and 0.86 for older groups. The test-retest reliability values were observed to be $0.86-0.91$ for the three age groups.

\section{Data Analyses}

SPSS Statistics 22 (Chicago, IL, USA) was used for statistical analysis. The comparison between the groups was performed using the Student t-test.

\section{Setting and Procedures}

We built our research work to find out the reasons for unemployment in the pandemic period in Ukraine. The study was divided into three parts. At the beginning of the research work, we formed a questionnaire with the idea to find out the reasons for job cuts in Ukraine right after the quarantine period started and checked the reliability of the instrument. The second stage was aimed to get known the participants' ideas about the causes of their own longterm unemployment. As long-term unemployment has a negative influence both on person and society, we aimed the final stage of our research to analyse the subjective ideas of our participants about possible ways out of the unemployment situation and do a statistical comparison and data analyses.

\section{RESULTS}

The first scale of the questionnaire had an aim to highlight the reasons for job cuts in gender groups. We received responses to the question "Why did you lose your job?", containing 87 subjective causes of unemployment. We grouped them into 11 blocks. The results of the grouped answers are presented in Table 1.

As can be seen from Table 1, the most typical cause of job loss of the participants among males of younger age group 18-25 years old was coronavirus job cuts. The youngsters were fired with a high percentage in the quarantine lockdown period when it started in Ukraine. The low qualification or lack of necessary education is the next reason for perceived Ukrainian job cuts; most of the young participants were accepted on probation for one position and upon its

Table 1: Subjective Reasons for Job Cuts

\begin{tabular}{|c|c|c|c|c|c|c|c|}
\hline \multirow{3}{*}{ № } & \multirow{3}{*}{ Blocks of reasons } & \multicolumn{6}{|c|}{ The frequency of naming the cause by the participants (\%) } \\
\hline & & \multicolumn{3}{|c|}{ Males } & \multicolumn{3}{|c|}{ Females } \\
\hline & & $\begin{array}{c}\text { younger } \\
(18-25)\end{array}$ & $\begin{array}{l}\text { middle } \\
(26-35)\end{array}$ & $\begin{array}{c}\text { older } \\
(36-50)\end{array}$ & $\begin{array}{c}\text { younger } \\
(18-25)\end{array}$ & $\begin{array}{l}\text { middle } \\
(26-35)\end{array}$ & $\begin{array}{c}\text { older } \\
(36-50)\end{array}$ \\
\hline 1 & Violation, disciplinary offenses & - & 19.1 & 20.4 & 10.5 & 17.2 & 4.1 \\
\hline 2 & Negative attitude of the leadership & - & 3.3 & 3.7 & 30.4 & 26.3 & 12.2 \\
\hline 4 & Inability to adapt to the team, own conflict & - & - & 4.3 & 10.7 & 15.3 & 17.4 \\
\hline 5 & Redundancy & - & 7.3 & 2.1 & 17.3 & - & 5.2 \\
\hline 6 & COVID job cut & 55.7 & 26.4 & 21.2 & 17.6 & 15.6 & 17.2 \\
\hline 7 & Inability to cope with responsibilities or withstand the work schedule & - & 5.2 & 7.7 & 4.9 & 8.2 & 11.2 \\
\hline 11 & Other reasons & - & 5.2 & 4.0 & 8.6 & 2.2 & 4.6 \\
\hline
\end{tabular}


completion transferred to another, with a different type of work and smaller wages. For example, the researched $M$. was accepted for the position of a fabric sales manager with a probationary period of 2 months, but after this time, he was offered the position of cashier, due to lack of experience as a manager, with career prospects).

Female $\mathrm{N}$. of the same age group (18 - 25-year-old) stated the negative attitude of the leadership. Most often, it was associated with the uncomfortable treatment by the management and its arbitrariness, redundancy (or liquidation of the enterprise), and other reasons such as sexual harassment.

Middle-aged male group (26-35-year-old) showed the ideas such as self-desire to leave the job (due to low wages; some participants said that they started their own business, and, in fact, they were not unemployed, receiving income informally); a violation, disciplinary offenses (the main violations committed by these men were absenteeism, appearance at work intoxicated and non-compliance with the terms of the employment contract); unfulfilled hopes, disappointment by the content of work; laziness, unwillingness to work with full effort, as required by the employer (showed frustration with work as such, saying that "... you need to work for yourself, not for that uncle", "... it's not worth it" etc.); impossibility of selfrealization and career growth ( $7.3 \%$ of people).

Middle-aged female at the age of 26-35 showed socio-psychological and personal reasons for own unemployment. We assume that a significant part of this group was women who did not work or continued childcare leave up to 6 years without retaining a position at the time of baby birth. Difficulty returning into the workforce, occupying a lower position compared to younger women, frequent illnesses of the child, cause conflict and dissatisfaction with work, were the main reasons for the dismissal of women in this age group.

The arbitrariness of management was associated with non-payment of wages during maternity leave, the imposition of obligations not provided in the employment contract, unfair bonuses, and unpaid leaves. For example, participant $A$. indicated that the manager paid only one sick leave per month, and working conditions were psychologically uncomfortable; could not withstand the workload $(15.6 \%$ after maternity leave); could not adapt to the team due to own conflict and unwillingness to cooperate with others.
Males of the older group at the age of $36-50$ answered that disciplinary misconduct and violations were the main reasons that led to the dismissal. They admitted own addiction to alcohol; they hoped that they would not be fired because of drinking as they had a long experience of work in one place or they were highly professional; coronavirus job cuts (they thought they would find a job quickly, because "such professionals are always in demand even while quarantine lockdown"); fatigue and oversaturation from work, unwillingness to work; lack of career growth (for example, the researched $\mathrm{K}$. said that he was offered a management position at another firm, he agreed, and resigned from his previous job, but did not get the position because he did not pass by competitive selection at the final stage).

The negative attitude of management (some noted pressure from management to free up the workplace for younger employees), inability to adapt to the new team, inability to cope with stress and work regime; due to deteriorating health; quarantine caused by COVID pandemic (mostly women, who can be fully supported by men) are the reasons to change status into unemployed in a female older group at the age of 3650.

Comparing the frequency of reasons for dismissal between the mentioned above groups of males and females using Student t-test, the following generalizations can be made:

COVID job cuts affect younger and older age groups more severe than the middle, 18-25 males are fired more often than the women of the same age $(p \leq 0.05)$;

- disciplinary misconduct and violations of labour legislation are more likely to be the reasons for the dismissal of men over 25 years of age than women $(p \leq 0.05)$;

- $\quad$ women over 25 are more often fired because of the negative attitude of management and their arbitrariness ( $p \leq 0.01)$, and women over the age of 35 are more often fired than men because of their own conflict and inability to build constructive relationships in the team $(p \leq 0.01)$;

men of all ages are more likely than women to be fired voluntarily $(p \leq 0.05)$;

- $\quad$ women elder 25 are fired more often than men because they cannot withstand the regime and workload $(p \leq 0.05)$; 
- $\quad$ men elder 25 are fired more often than women due to the frustration with the content of work ( $p$ $\leq 0.05)$.

In general, the main reasons for the dismissal except for the COVID lockdown of women were the negative features of the relationship developed in the workplace, in contrast to men, who were more often dismissed for objective reasons.

Unemployment is an urgent problem for Ukraine. The second part of our research was to find out the causes of ongoing unemployment. Some participants had more than six months of experience being unemployed, which indicates their failure in employment search, possible inadaptability of employment strategies.

To find out the reason of being unemployed we asked the participants the question "Why haven't you found a job yet? The answers to this question contained 39 subjective causes of long-term unemployment. We grouped them by content into 6 blocks. The results of the survey on the causes of longterm unemployment are shown in Table 2.

As we can see from Table 2, young men under the age of 25 consider the lack of vacancies for the desired qualification to be the main obstacle to employment. Men of the second and the third age groups show a lesser frequency of naming this barrier ( $p \leq 0.01)$. This suggests that older and more experienced men are better at finding vacancies and may have more job offer channels. This trend is not observed in the women's groups, but passivity in employment often occurs, regardless of age.
There is a growing awareness of the importance of education. With men, this figure ranges from $6.8 \%$ in the first group to $40.9 \%$ in the third, and the differences are statistically significant between all groups ( $p \leq$ 0.01). Similarly, in the women age groups, the rate of awareness of the lack of education for employment is $14.5 \%, 17.3 \%$, and $29.9 \%$, respectively. This indicates that more mature participants face the requirements of employers to improve education and skills but cannot meet them. Indeed, participants in the third age group point out that their education is somewhat outdated, but for the most part, they are not ready to improve it.

It is stated that in all age groups of men and women, there is approximately the same percentage of the unemployed who are satisfied with the current situation.

The sources of this satisfaction are as follows:

- $\quad$ men generally do not seek formal employment because they either receive informal income or are dependent on relatives. Some men, mostly of the third age group, show a protective nature of their passivity in search of work - they do not want to admit problems of being unemployed even at a very low quality of life;

- $\quad$ women in the older group, are mostly satisfied with receiving unemployment benefits or do not want to get a job because they are supported by their own husbands.

The career aspirations of the surveyed unemployed are declining in the age groups of women and men. Thus, the same percentage of young people under the age of 25 do not want to work "anywhere" and choose

Table 2: Participants' Ideas about the Causes of their Own Long-Term Unemployment

\begin{tabular}{|c|c|c|c|c|c|c|c|}
\hline \multirow{3}{*}{ № } & \multirow{3}{*}{ Causes of long-term unemployment } & \multicolumn{6}{|c|}{ Frequency of causes in the groups of participants (\%) } \\
\hline & & \multicolumn{3}{|c|}{ Males } & \multicolumn{3}{|c|}{ Females } \\
\hline & & $\begin{array}{c}\text { younger } \\
(18-25)\end{array}$ & $\begin{array}{l}\text { middle } \\
(26-35)\end{array}$ & $\begin{array}{c}\text { older } \\
(36-50)\end{array}$ & $\begin{array}{c}\text { younger } \\
(18-25)\end{array}$ & $\begin{array}{l}\text { middle } \\
(26-35)\end{array}$ & $\begin{array}{c}\text { older } \\
(36-50)\end{array}$ \\
\hline 1 & Lack of vacancies for the desired qualification & 52.9 & 33.1 & 15.0 & 18.3 & 11.8 & 12.9 \\
\hline 2 & Lack of necessary education or qualifications & 6.8 & 16.1 & 40.9 & 14.5 & 17.3 & 29.9 \\
\hline 3 & $\begin{array}{l}\text { Passivity in employment, } \\
\text { unemployment satisfaction }\end{array}$ & - & 20.4 & 26.2 & 25.0 & 26.4 & 25.7 \\
\hline 4 & Excessive requirements, unwillingness to work "anywhere" & 25.8 & 24.9 & 15.1 & 28.7 & 10 & 8.7 \\
\hline 5 & Barriers to employment (age, children, health status) & - & - & 2.8 & 10.6 & 22.9 & 8.3 \\
\hline 6 & $\begin{array}{c}\text { Social reasons (it is impossible to get a job at all, nepotism, } \\
\text { corruption, etc.) }\end{array}$ & 14.5 & 5.5 & - & 2.9 & 11.6 & 14.5 \\
\hline
\end{tabular}


a passive expectation of a more favourable, in terms of money or position, vacancy.

It was found that objective reasons hinder the employment of women more than men. This applies mainly to young women between the ages of 26 and 35 , who indicate having children as the main cause of unemployment. Among women under the age of 25, there are many statements that employment is hampered by personal life.

A certain percentage of participants consider general socio-economic reasons to be the main causes of long-term unemployment. It should be noted that most of the participants tried to give answers to this category during the interviews, but in an open section of the questionnaire, they formulated reasons from other blocks. At the same time, some of the participants did not change their point of view, even when asked to clarify, shifting the responsibility for their own unemployment to the state or society. This is especially true for young men under the age of 25 and women over the age of 35 . The main socio-economic causes of their own long-term unemployment, they believe are:

- $\quad$ nepotism ("... it is impossible to get a job if you are not a relative of the boss"),

- $\quad$ lack of jobs ("... there is no place to work in this country"),

- $\quad$ corruption ("... require a rollback"),

- $\quad$ state policy in the field of education ("... why we were taught if there is no place to work"), etc.
Summarizing the causes of long-term unemployment, it can be noted that the basic among them was the passivity of the unemployed, their inertia, propensity for unproductive employment strategies, and the low effectiveness of public policy in retraining and training of the unemployed.

Unemployment is a negative phenomenon in the economic and social environment of the country. The main adverse effects are social and economic character. Social effects are as follows: increased social tension, decline in the labour activity, increase in the number of crimes, increase in the number of mental diseases, deepening of social differentiation. Economic effects are the following ones: reduction in tax revenues, decline in living standards, reduction in GNP and GDP, cutback in production, etc. Thus, unemployment leads to severe economic and social consequences. Being unemployed for a long time has a negative influence on the future, finding the job. So, it is important to find out the ways of the unemployed situation. To understand the subjective ideas about possible ways out of unemployment, we analysed the results from the final question of our survey.

To the question "How can one find a job?" we received many original answers, which were further grouped by content into 8 blocks.

The results of the survey on possible ways out of unemployment are shown in Table 3.

The Table 3 data show that young unemployed men under the age of 25 prefer mainly active ways of employment: searching for vacancies in newspapers, the Internet, sending relevant resumes, deepening

Table 3: Participants ' Ideas about Possible ways out of the Unemployment Situation

\begin{tabular}{|c|c|c|c|c|c|c|c|}
\hline \multirow{3}{*}{ № } & \multirow{3}{*}{ Ways out of unemployment } & \multicolumn{6}{|c|}{ Frequency of ways in the groups of participants (\%) } \\
\hline & & \multicolumn{3}{|c|}{ Males } & \multicolumn{3}{|c|}{ Females } \\
\hline & & $\begin{array}{c}\text { younger } \\
(18-25)\end{array}$ & $\begin{array}{l}\text { middle } \\
(26-35)\end{array}$ & $\begin{array}{l}\text { older } \\
(36-50)\end{array}$ & $\begin{array}{c}\text { younger } \\
(18-25)\end{array}$ & $\begin{array}{l}\text { middle } \\
(26-35)\end{array}$ & $\begin{array}{c}\text { older } \\
(36-50)\end{array}$ \\
\hline 1 & Assistance of relatives in employment & 14.5 & 5.5 & 9.3 & 22.2 & 26.4 & 26.8 \\
\hline 2 & Help of friends in employment & 22.2 & 24.6 & 12.7 & 12.2 & 9.0 & 9.9 \\
\hline 3 & Mastering a new profession, continuing education & 19.8 & 20.4 & 9.3 & 25.0 & 17.3 & 8.3 \\
\hline 4 & Search for vacancies in newspapers, the Internet & 29.9 & 13.0 & 12.7 & 22.2 & 11.8 & 11.4 \\
\hline 5 & Search for at least a temporary job & 6.8 & 11.9 & 7.6 & 9.1 & 9.0 & 12.9 \\
\hline 6 & Being registered at the employment centre (and nothing more) & - & 7.6 & 19.4 & - & 11.8 & 12.9 \\
\hline 7 & All ways are tested, there is no way out & - & 9.7 & 21.1 & 6.4 & 4.6 & 11.4 \\
\hline 8 & Other ways & 6.8 & 7.3 & 7.9 & 2.9 & 10.1 & 6.4 \\
\hline
\end{tabular}


education or retraining, searching for temporary work. At the same time, a significant part of them seeks to find a job without making significant efforts: they hope to help friends and relatives. As other ways out of the unemployment situation, participants consider a change of residence, search for business partners, crime.

Approximately the same tendencies are observed in the female group of the same age. They are more likely than men to seek additional education and rely on the help of relatives in finding vacancies, somewhat less willing to look for work through the media, and with the help of friends. Among other ways to find work, the women named prostitution.

At the same time, men and women of the youngest age group did not consider being registered at the employment centre sufficient for employment.

Men aged 26-35 mostly hope for the help of friends in getting a job and are convinced that it is necessary to deepen their education level. Participants have despair in relatives as channels for overcoming the unemployment situation, and they are not very confident in the effectiveness of the media. Unlike men, women of this age group often consider relatives, and especially men, the best means of employment.

In this age group, there are participants who believe that it is enough to be registered at the employment centre to look for a job. In addition, there is a percentage of the unemployed who are convinced that they are just unable to get a job. This indicates the frustration of some participants and their disbelief in their own strength to build a further life path.

Passive employment strategies predominate among men of the third age group: $19.4 \%$ consider it sufficient to be registered at the employment centre, and $21.1 \%$ do not see employment opportunities at all. Participants chose other employment strategies almost equally. Another controversial way out of employment in this group was begging.

Women of the older age group consider relatives' help to be the most effective way of employment. Other strategies were chosen with approximately the same frequency. Some women consider being registered at the employment centre as the only available opportunity to find a job, and some do not believe in the possibility of finding a job at all.

The economic downturn, as well as the reduction of business activities, provoked an increase in the unemployment rate in pandemic shutdown. Some companies went bankrupt while others started cutting expenses, including those for staff. The decrease in the unemployment rate will stimulate the growth of the Ukrainian economy after all stages of quarantine ended. At the same time overcoming this challenge requires several changes, including the formation of the demand for certain specialists from the side of the government, the introduction of relevant education, better supply/demand in qualifications regulation and subsidies and as well as the implementation of comprehensive economic reforms supplemented with investments attraction.

\section{DISCUSSION}

Unemployment is a complex and multifaceted construct that involves situational (non-employment), motivational (seeking work), medical and legal aspects (being available for work) [4:597]. Unemployed people are therefore, those who are able to work, are allowed to work, and prefer to work but cannot find the job.

Unemployment is a serious issue in most countries in the world, but for some countries (e.g., the United States, New Zealand, Spain, and Taiwan), the problem has become severe because of the financial crisis that developed after 2007 [5]. Unemployment has also been a serious problem facing South Africa [6-8]. According to Contogiannis [6], the unemployment rate in South Africa increased from 13 per cent in the 1993 year to 26 per cent in the 2007 year (excluding discouraged workers, that is, people who had opted out of the labour market). Unemployment affects economic welfare, production, the erosion of human capital, social exclusion, crime, and social instability [7, 9].

The negative consequences of unemployment for well-being have been well documented [10, 11]. Hanisch [12] separates the negative effects of unemployment into individual and family effects. Individual effects include physical and psychological effects. Physical effects include an increase in headaches, stomach aches, sleep problems, lack of energy, hypertension, heart disease, and kidney disease. Psychological effects include increased hostility, depression, anxiety, stress, anger, fear, despair, loneliness and social isolation, and decreased self-esteem, life satisfaction, aspiration levels, concentration, and personal identity. Family effects include an increase in spousal abuse, marital friction, spousal depression, family conflict, child abuse, and a decrease in family cohesion and children's well-being. 
Lucas, Clark, Georgellis, and Diener [13] showed that, although life satisfaction is moderately stable over time, unemployment affects this long term.

Psychologists note that Ukrainian workers face a future of uncertainty in the near term, and they will be struggling to regain their positions even after the crisis passes. The European unemployment problem today is still at least as relevant as it was in the late eighties. Psychologists demonstrate that mental health is worsened by unemployment. Several studies ranging from the research papers in medicine to those in the social sciences and economics have shown that unemployment is associated with worse health outcomes, e.g. [14-16].

Ukrainian jobless need to discover powerful approaches to diminish worry in their own lives, and they face an assortment of stressors. Korniienko, Barchi [17] found out that most Ukrainian unemployed of any age were in stress. A critical extent feels their adapting capacities as insufficient. They report this stress influences their well-being, both physiologically and inwardly.

Social isolation has been reported as a risk factor for psychosis. Studies of the relationship between unemployment and mental health suggest that the opportunity for interpersonal contact may be an important contributing factor for psychosis [18]. And in some cases, it even convinces a person to commit crime and suicide. There is widespread concern that suicide rates increase in countries affected by the global economic crisis, in view of evidence that economic downturns and associated rises in unemployment are followed by increases in suicide [19].

If to consider the results of our research, unemployment, particularly when unexpected or involuntary, a colossal body of logical facts demonstrates that unemployed people have a lower level of psychological well-being than those who are employed. Psychological problems arising out of unemployment include fear, frustration, irritability, declining self-respect, sense of time losing its meaning, and action as futile, lonely, apathy, resignation, depression, anxiousness, and demoralisation.

Studies have shown that unemployed people tend to report less access to the latent functions than do those employed, while those with less access generally experience lowered physical and psychological well- being $[11,20,21]$. So, the latent functions might be partially provided in activities other than employment, such as meaningful leisure activities or attending workrelated training [22]. In the current research, the participants proved problems with access to those latent functions and the lack of possibilities to be involved in the activities other than employment due to the low life quality of life of the most unemployed.

Paul and Moser [4] found that the employment commitment of both employed and unemployed people was high. However, employed people showed a marginally stronger level of employment commitment. Basing their approach to consistency theory [23], Paul and Moser [4] explain the unwell-being, psychological distress, and dissatisfaction of unemployed people in terms of the incongruence between their goals and their perceived goal attainment. Individuals who are strongly committed to work will see their job search as incongruent if it is unsuccessful, with detrimental consequences. Employment commitment could mitigate or buffer the negative consequences of unemployment [24].

Unemployed males and females might differ regarding experiences, attitudes, and behaviours for various reasons. First, males might be more inclined to experience unemployment negatively because of the sex-role stereotypes that make males breadwinners. Second, females might find it more difficult to get jobs because of gender discrimination, which could affect their affective experiences [5]. However, this problem was not highlighted in the answers of the participants in our current research.

When it comes to age, older people might experience unemployment more negatively than younger people, especially if they find it difficult to get a job [5], which in general complies with the current research results. According to a diagnostic overview by the National Planning Commission [8], unemployment is experienced mostly by young people (15-34 years), who are also poorly prepared for work.

De Witte et al. [25] found that people who were unemployed in the short term experienced more psychological distress, showed more employment commitment, and applied for jobs more often than those who were unemployed in the long term. They attributed these findings to an adaptation process that took place in long-term unemployed people, whereby their psychological well-being increased after a while. As we see from the current research, long term 
unemployed gradually lose the string desire to find a job and adopt to being unemployed, even maintaining a very low quality of life.

Our research uncovered that the joblessness in Ukraine among all laborers indicated a distinctive perception of the purposes for job cuts, and their thoughts regarding potential routes out of the unemployment in the circumstance of a COVID lockdown in Ukraine demonstrated the age gap in the activity cuts perception. The investigation gives further bits of knowledge into the labour market and perception of both males and females of various age groups in the principal phase of a COVID lockdown. As a result, we found both the cognitive and behavioural patterns of the unemployed participants. The most significant is the passivity of the unemployed, their inertia and unproductive employment strategies, a decline in trust to the media as employment search, and a growing tendency to despair of the ability to find a job. Growing understanding of the education importance is considered a positive side of their cognitive attitudes and patterns.

\section{CONCLUSIONS}

The Coronavirus pandemic is having a huge impact on the European labour market. The International Labour Organization foresees the loss of 12 million fulltime jobs in Europe in 2020. The rise in the number of unemployed workers due to COVID-19 is substantially greater than the increase due to different problems before. Unemployment in Ukraine among all groups of workers increased sharply in the COVID-19 recession. But the experiences of several groups of workers, such as women and men, vary notably in the COVID-19 outbreak.

The research ideas presented in this manuscript have been offered as the ways to find out how the perception of the reasons for job cuts males and females shifted in the first stage of lockdown, check and compare the male's and female's ideas about the causes of their own long-term unemployment and their ideas about possible ways out of the unemployment in the situation of a COVID lockdown in Ukraine. Summarizing the research done by us at the beginning of the quarantine period, the following trends should be noted:

- in all age groups increased inflows from employment into unemployment in April 2020 were due to the shutdown measures;
COVID situation may cause long-term unemployment as an acute problem because the longer people are out of work, the more problematic it is to return to professional activity;

- younger and older age groups are affected by COVID job cuts more severe than the middle, 18-25 males are fired more often than the women of the same age $(p \leq 0.05)$;

- $\quad$ men older the age of 25 rely less on the help of relatives in employment $(p \leq 0.05)$, in contrast to them, women believe more in the ability of relatives, and especially their husbands, to help to employ them;

- $\quad$ men becoming elder hopes for the help of friends in finding a job ( $p \leq 0.05$ between the second and third groups) decrease; women generally have little hope for friends in solving this problem. The unemployed likely have a narrowing of social contacts, and women react more sharply, not wanting to seek help from friends and acquaintances;

- older women are less likely to believe in education as a means of employment ( $p \leq 0.05)$, considering insufficient education as one of the main factors of unemployment, women are not ready to study;

- $\quad$ unemployed men and women with age have a decline in trust in the media as employment channels and a growing tendency to despair of their ability to find work;

- $\quad$ the situation when a person despairs finding a job may lead to immoral or criminal ways of earning.

Based on the results of our research Labor centers should take into consideration the following actions, principles, and rules: increase in individualised support through re-assessment of the needs and employment prospects and a job integration agreement; strengthen continuity in support of the unemployed through a coordinated service offer involving available employment and social support services through a single point of contact; increase the engagement of employers in programmes targeting long term unemployed.

Within the general theme of youth employment and opportunity, it's important to develop effective models 
of cooperation, make education and vocational education and train responsive to the needs of the local labour market, match employment and demand by improving analysis and forecast of labour market evolution and needs, support for business creation and development, self-employment.

In closing, we are humbled by the stories told by our participants about the job loss of this pandemic period. We hope that our readers will find the ideas in our research work that may stimulate a broad-based research agenda for the field of people suffering from the loss of work.

\section{LIMITATIONS AND FURTHER RESEARCH}

This study has multiple methodological limitations, which may be addressed in future research. All data were self-reported. There was no personal interaction with the participants, and the instrument verification stage was limited in time and quantity. Moreover, there is a need for replication of these results in longitudinal studies. Considering the results, we recommend arranging more detailed, both objective and subjective research of the current stage on the unemployment involving Job Centres activities investigation to have the basis for the roadmap of possible government actions and policies in educational, investing, and regulation spheres.

\section{ACKNOWLEDGEMENTS}

We express our heartiest gratitude to Tetiana Scherban, Rector of Mukachevo State University, Dr in Psychology, a professor who provided us with a welcoming environment to do our research. We are also grateful to overwhelm in all humbleness and gratefulness to acknowledge the occupation of the science employees of MSU for their precious contribution to research. We are sincere gratitude to those whose names are not mentioned, but they had helped and coordinated us. We are sure that with their support, it has been possible for us to smoothly complete our research and present its results in this paper.

\section{REFERENCES}

[1] Kochhar R. Unemployment rose higher in three months of COVID-19 than it did in two years of the Great Recession. JUNE 11, 2020. https://www.pewresearch.org/facttank/2020/06/11/unemployment-rose-higher-in-three-monthsof-covid-19-than-it-did-in-two-years-of-the-great-recession/

[2] Temko N. No jobs, so what future? Half the world's workforce on the edge. The Christian science monitor. https://www.csmonitor.com/World/2020/0506/No-jobs-sowhat-future-Half-the-world-s-workforce-on-the-edge
[3]

Antoniuk D. Ukraine's unemployed rises by 156,000 amid the pandemic https://www.kyivpost.com/business/ukrainesunemployed-grow-by-156600-amid-the-pandemic.html

[4] Paul KI, Moser K. Incongruence as an explanation for the negative mental health effects of unemployment: metaanalytic evidence. Journal of Occupational and Organizational Psychology 2006; 79(4): 595-621. https://doi.org/10.1348/096317905X70823

[5] Wanberg CR. The individual experience of unemployment. Annual Review of Psychology 2012; 63: 369-396. https://doi.org/10.1146/annurev-psych-120710-100500

[6] Contogiannis T. Economic growth, constraints and prospects for the South African economy. Discourse 2007; 35(2): 3844.

[7] Kingdon GG, Knight J. Race and the incidence of unemployment in South Africa. London: Blackwell 2004. https://doi.org/10.1111/j.1467-9361.2004.00228.x

[8] National planning commission. Diagnostic overview. Cape Town, South Africa: Department of the Presidency 2011.

[9] Dollard MF, Winefield AH. Mental health: overemployment, underemployment, unemployment and healthy jobs. Australian e-Journal for the Advancement of Mental Health 2002; 1(3): 10-11.

https://doi.org/10.5172/jamh.1.3.170

[10] Creed PA, Watson T. Age, gender, psychological well-being and the impact of losing the latent and manifest benefits of employment in unemployed people. Griffith University, Australia. De Witte H, Hooge J, Vanbelle E. 2010. Do the long-term unemployed adapt to employment? Romanian Journal of Applied Psychology 2003; 12: 8-14.

[11] McKee-Ryan FM, Song Z, Wanberg CR, Kinicki AJ. Psychological and physical well-being during unemployment: a meta-analytic study. Journal of Applied Psychology 2005; 90: 53-75.

https://doi.org/10.1037/0021-9010.90.1.53

[12] Hanisch KA. Job loss and unemployment research from 1994 to 1998: a review and recommendations for research and intervention. Journal of Vocational Behavior 1999; 55: 188-220.

https://doi.org/10.1006/jvbe.1999.1722

[13] Lucas RE, Clark AE, Georgellis Y, Diener E. Unemployment alters the set point for life satisfaction. Psychological Science 2004; 15(1): 8-13.

https://doi.org/10.1111/j.0963-7214.2004.01501002.x

[14] Broomhall HS, Winefield AH. A comparison of the affective well-being of young and middle-aged unemployed men matched for length of unemployment. British Journal of Medical Psychology 1990; 63: 43-52. https://doi.org/10.1111/j.2044-8341.1990.tb02855.x

[15] Johansson E, Böckerman P, Lundqvist A. Self-reported health versus biomarkers: does unemployment lead to worse health? Public Health 2020; 179: 127-134. https://doi.org/10.1016/i.puhe.2019.10.005

[16] Mathers N, Fox N, Hunn A. Trent Focus for Research and Development in Primary Heath Care: Using Interview in a Research Project. Sheffield: Trent Focus Group 1998.

[17] Korniienko I, Barchi B. Enriching the coping behavior repertoire and motivation of the unemployed using metaphors. International Journal of Scientific \& Technology Research 2020; 9(04): 1416-1422.

[18] Reininghaus UA, Morgan C, Simpson J, et al Unemployment, social isolation, achievement-expectation mismatch and psychosis: findings from the ÆESOP Study. Soc Psychiat Epidemiol 2008; 43: 743-751. https://doi.org/10.1007/s00127-008-0359-4

[19] Chang EC, Chang OD. Development of the frequency of suicidal ideation inventory: Evidence for validity and reliability of a brief measure of suicidal ideation frequency in a college 
student population. Cognitive Therapy and Research 2016; 40: 549-556.

https://doi.org/10.1007/s10608-016-9758-0

[20] Creed PA, Macintyre SR. The relative effects of deprivation of the latent and manifest benefits of employment on the well-being of unemployed people. Journal of Occupational Health Psychology 2001; 6(4): 324-331.

https://doi.org/10.1037/1076-8998.6.4.324

[21] Paul Kl, Batinic B. The need for work: Jahoda's latent functions of employment in a representative sample of the German population. Journal of Organizational Behavior 2009; 30: 1-19. https://doi.org/10.1002/job.622

[22] Creed PA, Muller J, Machin MA. The role of satisfaction with employment status, neuroticism, financial strain and categories of experience in predicting mental health in the unemployed. Personality and Individual Differences 2001; 30 (3): 435-447. https://doi.org/10.1016/S0191-8869(00)00035-0

[23] Grawe K. Psychological therapy. Seattle: Hogrefe \& Huber. 2004.

[24] Fryer D, Fagin R. Coping with unemployment. International Journal of Political Economy 1993; 23(15): 95-120. https://doi.org/10.1080/08911916.1993.11643866

[25] De Witte H, De Cuyper N, Handaja Y, Sverke M, Näswall K, Hellgren J. Associations between quantitative and qualitative job insecurity and well-being. A test in Belgian banks. International Studies of Management \& Organization 2010; 40(1): 40-56. https://doi.org/10.2753/IMO0020-8825400103

DOI: https://doi.org/10.6000/2292-2598.2020.08.03.30

(C) 2020 Korniienko and Barchi; Licensee Lifescience Global.

This is an open access article licensed under the terms of the Creative Commons Attribution Non-Commercial License (http://creativecommons.org/licenses/by-nc/3.0/) which permits unrestricted, non-commercial use, distribution and reproduction in any medium, provided the work is properly cited. 